\title{
ANALISA NILAI TAMBAH PENJUALAN JAMUR TIRAM SEGAR DAN KERIPIK JAMUR TIRAM DI DESA BUMIRAHAYU KECAMATAN BUAY MADANG TIMUR KABUPATEN OKU TIMUR
}

\author{
(Hariyono) \\ Sekolah Tinggi Ilmu Pertanian Belitang \\ JIn.Kampus Pertanian No.3 Belitang Kab.OKU Timur Prov.Sumatera Selatan \\ e-mail: hariyono.ss@gmail.com
}

\begin{abstract}
The purpose of this study is to: (1) To know the income of the business of selling fresh oyster mushroom and the manufacture of oyster mushroom chips in Bumirahayu Village, Buay Madang Timur Regency, OKU Timur Regency, (2) To know the value added value of fresh oyster mushroom sales into oyster mushroom chips In Bumirahayu Village, Buay Madang Timur District, East OKU Regency. This research is from January to February 2015 on the cultivation of oyster mushroom and the business of making oyster mushroom chips in Kelompok Wanita Tani (KWT) "Melati" Bumirahayu Village, Buay Madang Timur District OKU Timur Regency with case study method. This study found that the income obtained by oyster mushroom cultivation business is Rp. 10.953.697, - / PP (Rp 2.738.424, - / Month). As for the business of making oyster mushroom kripik is Rp. 988. 437, - / PP (Rp 3.953.748, - / Month). The existence of a considerable income difference causes the business of making oyster mushroom crackers deserve to be developed and added value on the business of making oyster mushroom kripik is Rp. 12.437, - I Kg or Rp. 1.305.937, - / PP (Rp 5,223,748, - / Month) obtained from the final difference with the cost of the raw materials.
\end{abstract}

Key Words : Oyster mushroom, Value-added, Income.

\section{PENDAHULUAN}

\section{A. Latar Belakang}

Agribisnis merupakan salah satu kegiatan yang bergerak di bidang pertanian mulai dari pengusahaan sarana produksi (input) pertanian maupun pengusahaan produksi pertanian serta pengusahaan pengelolaan hasil (output) pertanian. Oleh sebab itu, agribisnis mencakup keseluruhan kegiatan produktif mulai dari perangkat keuangan, kepegawaian dan pemasaran meskipun yang melakukan usaha atau kegiatan adalah petani kecil yang bersifat komersil (Sjarkowi, 2010).

Kabupaten OKU Timur merupakan salah satu kabupaten baru yang sedang berkembang, sehingga diperlukan adanya intensifikasi dan ekstensifikasi di bidang pertanian dalam meningkatkan hasil produksi pertanian untuk membantu pertumbuhan pembangunan pertanian menuju ketersediaan dan ketahanan pangan yang selalu berkesinambungan. Peningkatan hasil produksi pertanian yang bersifat konsumtif tidak cukup dengan membudidayakan tanaman padi dan palawija saja akan tetapi sayuran juga sangat penting untuk dikonsumsi oleh masyarakat sebagai bahan pelengkap kebutuhan sumber vitamin (Sunarjono, 2010).
Jamur tiram merupakan salah satu dari jenis jamur kayu yang bisa dikonsumsi, dengan bentuk tudung jamur yang menyerupai cangkang tiram. Jamur tiram sudah dikenal masyarakat luas baik di Indonesia maupun di negara lain. Pembudidayaan jamur tiram di Indonesia dimulai sejak tahun 1980 di Wonosobo, dan permintaan jamur tiram mengalami peningkatan pada setiap tahunnya. Peningkatan tersebut berkaitan dengan pengetahuan masyarakat akan khasiat dan kandungan gizi pada jamur tiram. Menurut catatan Tabloid Peluang Usaha yang terbit pada tahun 2009, kebutuhan jamur tiram untuk wilayah Jakarta mencapai 15 ton per hari dan Bandung mencapai 7-19 ton per hari (Cahyana, 2008).

Tingginya jumlah permintaan jamur tiram dapat memotivasi masyarakat untuk lebih banyak membudidayakan jamur tiram. Budidaya jamur tiram dapat berhasil dengan baik apabila ditunjang dengan ilmu pengetahuan yang luas mengenai semua aspek mulai dari manfaat dan kegunaan, varietas, mutu benih, tekhnik budidaya, kondisi lingkungan bertanam, penanganan panen sampai pasca panen, dan analisis usaha (Redaksi Trubus, 2010). Keberhasilan usaha budidaya jamur tiram dipengaruhi oleh beberapa faktor yang perlu mendapat perhatian khusus. Hal tersebut 
dilakukan untuk menjaga agar produksi jamur tiram sesuai dengan yang diharapkan. Faktorfaktor tersebut antara lain penggunaan bibit unggul, pengolahan media, perawatan dan pemeliharaan (Djarijah dan Abbas, 2010).

Desa Bumirahayu Kecamatan Buay Madang Timur Kabupaten OKU Timur, merupakan salah satu desa yang salah satu warganya membudidayakan jamur tiram putih secara komersil sebagai tanaman sayur. Produksi jamur tiram putih di Desa Bumirahayu masih rendah apabila dibandingkan dengan produksi jamur tiram putih secara nasional, meskipun Desa Bumirahayu sebenarnya memiliki potensi untuk usaha budidaya jamur tiram putih. Menurut Redaksi Majalah Trubus (2004), faktor lain yang mendukung adalah banyaknya manfaat jamur tiram yang terkandung di dalamanya antara lain sebagai antikolesterol, mencegah penyakit kanker dan anemia, mengurangi risiko cacat kelahiran dan cacat otak pada anak.

Tabel 1. Kandungan Gizi Jamur Tiram per 100 Gram.

\begin{tabular}{clr}
\hline No. & \multicolumn{1}{c}{ Jenis Kandungan Gizi } & Jumlah dalam Persen $(\%)$ \\
\hline 1. & Lemak & 0,17 \\
2. & Protein & 5,94 \\
3. & Karbohidrat & 50,59 \\
4. & Abu & 1,14 \\
5. & Serat & 1,56 \\
\hline
\end{tabular}

Sumber: Daftar Analisis Bahan Makanan, Fak. Kedokteran UI, Jakarta, 2000.

Berdasarkan tabel di atas maka kandungan gizi pada jamur tiram adalah karbohidrat sebesar $50,59 \%$, sedangkan kandungan gizi yang terendah adalah lemak sebanyak $0,17 \%$. Bayaknya manfaat yang terkandung pada jamur tiram dan peluang pasar yang masih terbuka luas menyebabkan Kelompok Wanita Tani "Melati" (Ibu-ibu PKK) di Desa Bumirahayu mengolah hasil produksi jamur tiram menjadi berbagai macam makanan olahan salah satunya adalah kripik jamur tiram. Pembuatan kripik jamur tiram selain tidak membutuhkan modal yang terlalu besar, proses pembuatannya juga tidak terlalu sulit. Proses pembuatan kripik jamur tiram putih membutuhkan keuletan dan ketrampilan untuk menghasilkan produk makanan yang sehat dan bergizi yang pada akhirnya usaha pembuatan keripik jamur tiram putih dapat mendatangkan keuntungan yang maksimal.

Usaha pembuatan kripik jamur tiram merupakan salah satu usaha memberikan nilai tambah pada jamur tiram selain dijual dalam keadaan segar. Hal tersebut dilakukan karena selain dapat mendatangkan keuntungan bagi pelaku usaha, peluang usahanya juga masih terbuka luas.

\section{B. Rumusan Masalah}

1. Berapa besar pendapatan usaha penjualan jamur tiram segar dan pembuatan kripik jamur tiram di Desa Bumirahayu Kecamatan Buay Madang Timur Kabupaten OKU Timur.

2. Berapa besar nilai tambah penjualan jamur tiram segar menjadi kripik jamur tiram di Desa Bumirahayu Kecamatan Buay Madang Timur Kabupaten OKU Timur.

\section{Tujuan dan Kegunaan}

1. Untuk mengetahui pendapatan usaha penjualan jamur tiram segar dan pembuatan kripik jamur tiram di Desa Bumirahayu Kecamatan Buay Madang Timur Kabupaten OKU Timur.

2. Untuk mengetahui besar nilai tambah penjualan jamur tiram segar menjadi kripik jamur tiram di Desa Bumirahayu Kecamatan Buay Madang Timur Kabupaten OKU Timur.

\section{Model Pendekatan}

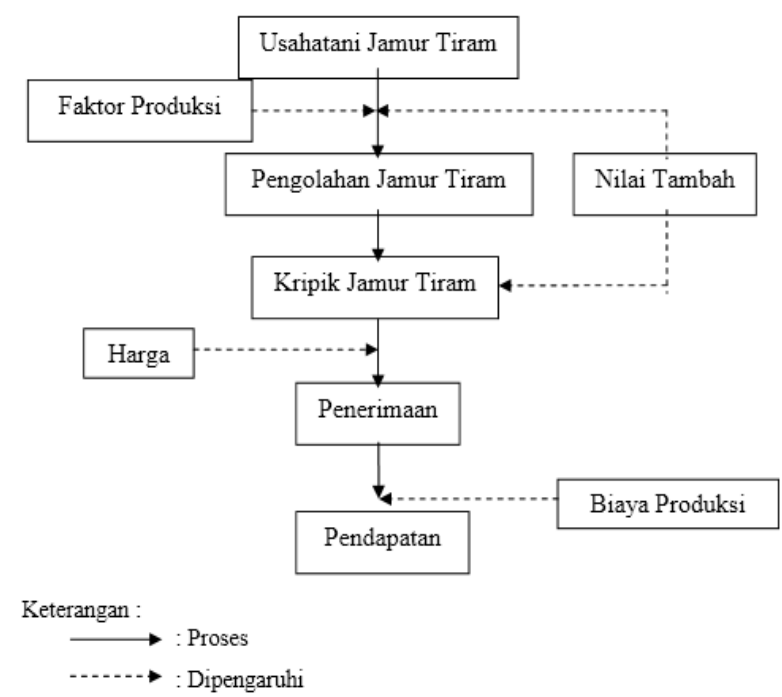

Gambar 1. Model pendekatan penelitian secara diagramatik

\section{METODOLOGI PENELITIAN}

\section{A. Tempat dan Waktu}

Penelitian ini dilaksanakan pada Bulan Januari sampai dengan Bulan Februari 2015 pada usaha budidaya jamur tiram dan usaha pembuatan kripik jamur tiram di Kelompok Wanita Tani (KWT) "Melati" Desa Bumirahayu Kecamatan Buay Madang Timur Kabupaten OKU Timur. 


\section{B. Metode Penelitian}

Metode penelitian yang digunakan adalah metode case study, metode ini dapat digunakan untuk mengamati data dan masalah yang dapat dijadikan objek penelitian. Menurut Sopiah (2010), metode studi kasus adalah sebuah metode penelitian yang secara khusus menyelidiki fenomena kontemporer yang terdapat dalam kontek kehidupan yang nyata, dan dilaksanakan ketika batasan-batasan menggunakan berbagai sumber data dalam kaitannya dengan waktu dan tempat usaha budidaya jamur tiram dan usaha pembuatan kripik jamur tiram di Desa Bumirahayu Kecamatan Buay Madang Timur Kabupaten OKU Timur.

\section{Metode Penarikan Contoh}

Metode penarikan contoh yang digunakan adalah metode sensus. Menurut Etta dan Sopiah (2010), metode sensus adalah metode dimana pengambilan sampel dilakukan secara sengaja terhadap 1 populasi dan sekaligus menjadi responden yaitu pelaku usaha budidaya jamur tiram dan usaha pembuatan kripik jamur tiram di Kelompok Wanita Tani (KWT) "Melati" Desa Bumirahayu Kecamatan Buay Madang Timur Kabupaten OKU Timur.

\section{Metode Pengolahan Data}

Data yang diperoleh dari penelitian selanjutnya diolah secara tabulasi dan dianalisis secara matematik dan dideskritifkan.

1. Untuk mengetahui besarnya pendapatan:

a) Menurut Kuswadi (2007), untuk mengetahui biaya produksi maka digunakan rumus:

$\mathrm{TC}=\mathrm{FC}+\mathrm{VC}$

Dimana:

TC : Total Cost (Total Biaya)

FC : Fixed Cost (Biaya Tetap)

VC: Variabel Cost (Biaya Tidak Tetap)

b) Menurut Mulyadi (2007), untuk mengetahui besarnya penerimaan maka digunakan rumus: $\mathrm{R}=\mathrm{Y} \times \mathrm{P}$

Dimana:

$\mathrm{R}$ : Revenue (Penerimaan)

Y: Yield (Hasil Produksi)

$\mathrm{P}$ : Price (Harga)

c) Menurut Samoelson dan Naredhous (2000), untuk mengetahui besarnya pendapatan maka digunakan rumus:

$\mathrm{I}=\mathrm{R}-\mathrm{TC}$

Dimana:

I : Income (Pendapatan)

$\mathrm{R}$ : Revenue (Penerimaan)
TC : Total Cost (Total Biaya)

2. Untuk Mengetahui Nilai Tambah:

Menurut Ibrahim (2009), untuk mengetahui nilai tambah maka digunakan rumus:

$\mathrm{NT}=\mathrm{TR}-\mathrm{IC}$

Dimana:

NT : Nilai Tambah

TR : Total Revenue/Total Penerimaan

IC : Intermediate Cost/Biaya Antara.

\section{HASIL DAN PEMBAHASAN}

\section{Analisis Nilai Tambah Pembuatan Kripik Jamur Tiram}

1. Total Biaya Produksi (Total Cost)

Menurut Assauri (2006), biaya produksi adalah semua pengeluaran yang dilakukan oleh perusahaan untuk faktor-faktor produksi, sehingga memperoleh output. Sedangkan, menurut Mulyadi (2009), biaya produksi adalah semua pengorbanan yang perlu dilakukan oleh produsen/perusahaan untuk suatu proses produksi, yang dinyatakan dengan satuan uang menurut harga pasar yang berlaku, baik yang sudah terjadi maupun yang akan terjadi. Korbanan atau biaya ini berada posisi yang harus seefesien mungkin agar mempunyai keuntungan yang optimal.

Biaya tetap adalah biaya yang tidak habis dalam satu kali proses produksi, yaitu biaya sewa tempat usaha baik untuk budidaya jamur tiram maupun untuk usaha pembuatan kripik jamur tiram serta total biaya penyusutan alat pada masing-masing usaha yang besaran nominalnya berbeda karena alat yang digunakan juga berbeda. Sedangkan biaya variabel adalah biaya yang habis dalam satu kali proses produksi, diantaranya biaya sarana produksi dan tenaga kerja.

Biaya sarana produksi untuk usaha budidaya jamur tiram antara lain bibit jamur, serbuk gergaji kayu, dedak, kapur dolomit, plastik ukuran $17 \mathrm{~cm}$ x $30 \mathrm{~cm}$, kayu bakar, cincin bambu, karet gelang, tepung jagung, kapas, koran, alkohol, dan pupuk diegro. Sedangkan sarana produksi untuk usaha kripik jamur tiram antara lain bahan baku/jamur tiram putih, minyak sayur, kayu bakar, tepung rose brand, tepung bumbu, tepung sagu, plastik ukuran $1 \mathrm{~kg}$ dan ukuran $1 / 2 \mathrm{~kg}$, bumbu dan biaya listrik sebagai bahan bakar untuk menyalakan mesin pengepres. Rincian ratarata biaya produksi untuk lebih jelasnya dapat dilihat pada tabel berikut:

Tabel 2. Rincian Rata-rata Biaya Produksi Perproses Produksi. 


\begin{tabular}{|c|c|c|c|}
\hline No. & Uraian & $\begin{array}{c}\text { Usaha Budidaya } \\
\text { Jamur Tiram ( } \pm 4 \text { Bln })\end{array}$ & $\begin{array}{c}\text { Usaha Kripik } \\
\text { Jamur Tiram }( \pm 7 \text { Hari })\end{array}$ \\
\hline \multicolumn{2}{|c|}{ 1. Biaya Tetap } & 1.789.803,- & 107.063,- \\
\hline \multicolumn{2}{|r|}{ - Sewa Tempat Usaha } & 1.666.667,- & 104.167,- \\
\hline \multicolumn{2}{|r|}{ - Biaya Penyusutan Alat (BPA) } & 123.136,- & 2.896,- \\
\hline & Biaya Variabel & 3.294.500,- & Rp. $3.314 .500,-$ \\
\hline & - Biaya Sarana Produksi & 1.098.500,- & Rp. $3.139 .500,-$ \\
\hline & - Biaya Tenaga Kerja & $2.196 .000,-$ & $175.000,-$ \\
\hline & Total Biaya & $5.084 .303,-$ & Rp. $\quad 3.421 .563,-$ \\
\hline
\end{tabular}

Sumber: Data Primer (Diolah), 2015.

Berdasarkan tabel di atas diketahui rata-rata besarnya biaya tetap yang dikeluarkan oleh pelaku usaha budidaya jamur tiram adalah Rp. 1.789.803,-/PP yang digunakan untuk sewa tempat usaha Rp. 1.666.667,-/PP dan biaya penyusutan alat Rp. 123.136,-/PP. Selain biaya tetap pelaku usaha juga mengeluarkan biaya variabel sebesar Rp. 3.294.500,-/PP diantaranya untuk biaya sarana produksi sebesar Rp. 1.098.500,-/PP serta untuk biaya tenaga kerja mulai dari pembuatan kumbung, pembibitan, pembungkusan, sterilisasi, dan perawatan Rp. 2.196.000,-/PP. Sehingga total dari keseluruhan biaya yang dikeluarkan oleh pelaku usaha selama satu kali poses produksi ( \pm 4 bulan) adalah jumlah dari biaya tetap ditambah dengan jumlah biaya variabel maka total biaya produksi adalah $\mathrm{Rp}$. 5.084.303,-/PP.

Sedangkan untuk usaha pembuatan kripik jamur tiram rata-rata besarnya biaya tetap yang dikeluarkan oleh pelaku adalah Rp. 107.063,-/PP yang digunakan untuk sewa tempat usaha Rp. 104.167,-/PP dan biaya penyusutan alat Rp. 2.896,-/PP. Selain biaya tetap pelaku usaha juga mengeluarkan biaya variabel sebesar $\mathrm{Rp}$. 3.314.500,-/PP diantaranya untuk biaya sarana produksi sebesar Rp. 3.139.500,-/PP serta untuk biaya tenaga kerja mulai dari pemilihan bahan baku, perendaman, pencucian, pengadonan, penggorengan, pengeringan dan pengemasan/pembungkusan sebesar Rp. 175.000,/PP. Sehingga total dari keseluruhan biaya yang dikeluarkan oleh pelaku usaha selama satu kali poses produksi ( \pm 7 hari) adalah jumlah dari biaya tetap ditambah dengan jumlah biaya variabel maka total biaya produksi adalah Rp. 3.421.563,/PP.

2. Produksi, Penerimaan, Pendapatan Perproses Produksi dan Nilai Tambah

Hasil penelitian di lapangan menunjukan bahwa untuk usaha budidaya jamur tiram putih menghasilkan $891 \mathrm{~kg} / \mathrm{PP}$. Sedangkan untuk usaha pembuatan kripik jamur tiram penyusutan produksi dari jamur tiram segar menjadi kripik jamur tiram tidak terlalu banyak, yaitu setiap 105 kg jamur tiram segar menjadi kripik jamur tiram $73,5 \mathrm{~kg}$ atau setiap $1 \mathrm{~kg}$ susut 0,7 .

Tabel 3. Rincian Rata-rata Produksi, Penerimaan, dan Pendapatan/PP

\begin{tabular}{|c|c|c|c|}
\hline No. & Uraian & $\begin{array}{l}\text { Usaha Budidaya } \\
\text { Jamur Tiram ( } \pm 4 \text { Bln })\end{array}$ & $\begin{array}{c}\text { Usaha Kripik } \\
\text { Jamur Tiram }( \pm 7 \text { Hari })\end{array}$ \\
\hline \multirow[t]{5}{*}{1.} & Produksi & & \\
\hline & - Jamur Tiram Putih Segar & $891 \mathrm{Kg}$ & $105 \mathrm{Kg}$ \\
\hline & - Kripik Jamur Tiram & - & $73,5 \mathrm{Kg}$ \\
\hline & - Kripik Jamur Tiram/1 Kg & - & 40 Bungkus \\
\hline & - Kripik Jamur Tiram/1/2 Kg & - & 67 Bungkus \\
\hline \multirow[t]{4}{*}{2.} & Harga & & \\
\hline & Harga Jamur Tiram Segar & $18.000,-/ \mathrm{Kg}$ & Rp. $60.000,-/ \mathrm{Kg}$ \\
\hline & Harga $1 \mathrm{Kg}(\mathrm{Rp} / \mathrm{Kg})$ & - & Rp. $60.000,-11 \mathrm{Kg}$ \\
\hline & Harga ${ }^{1 / 2} \mathrm{Kg}(\mathrm{Rp} / 1 / 2 \mathrm{Kg})$ & - & Rp. $30.000_{3}^{-1 / 1 / 2 \mathrm{Kg}}$ \\
\hline & Total Biaya Produksi (Rp/PP) & Rp. $5.084 .303_{3}-/ \mathrm{PP}$ & Rp. $3.421 .563_{-} / \mathrm{PP}$ \\
\hline & Penerimaan (Rp/PP) & Rp. $16.038 .000_{3}-\mathrm{PP}$ & Rp. $4.410 .000,-$ PP \\
\hline 5. & Pendapatan $(\mathrm{Rp} / \mathrm{PP})$ & Rp. 10.953.697,-/PP & Rp. $988.437,-$ PP \\
\hline 6. & Pendapatan (Rp/Bulan) & Rp. $2.738 .424,-/ B \ln$ & Rp. $3.953 .748,-/ \mathrm{Bln}$ \\
\hline & Nilai Tambah (Rp/PP) & - & Rp. 1.303.937, - PP \\
\hline & Nilai Tambah $(\mathrm{Rp} / \mathrm{Kg})$ & - & $\begin{array}{ll}\text { Rp. } & 12.437_{\mathrm{z}} / \mathrm{Kg} \\
\end{array}$ \\
\hline
\end{tabular}

Sumber: Data Primer (Diolah), 2015.

Pelaku usaha budidaya jamur tiram mampu menghasilkan jamur tiram putih segar sebanyak $891 \mathrm{~kg} / \mathrm{PP}$ dengan harga Rp. 18.000,-/kg. Sedangkan untuk usaha pembuatan kripik jamur tiram pelaku usaha menggunakan bahan baku berupa jamur tiram segar sebanyak $105 \mathrm{~kg} / \mathrm{PP}$ menjadi 73,5 kg/PP kripik jamur tiram dengan harga setiap $1 \mathrm{~kg}$ Rp. $60.000,-/ 1 \mathrm{~kg}$ dan harga untuk $1 / 2 \mathrm{~kg}$ adalah Rp. $30.000,-/ 1 / 2 \mathrm{~kg}$. Jumlah produksi kripik jamur tiram $1 \mathrm{~kg}$ adalah 40 bungkus/PP dan $1 \frac{1}{2} \mathrm{~kg}$ sebanyak 67 bungkus/PP sehingga total ada 107 bungkus/PP.

Harga akan mempengaruhi besarnya penerimaan pelaku usaha baik untuk usaha budidaya jamur tiram segar maupun untuk usaha pembuatan kripik jamur tiram, oleh sebab itu pelaku memilih menjual jamur tiram dalam bentuk makanan olahan yaitu kripik jamur tiram yang dijual di rumah, kecuali jika tidak habis maka kripik jamur tiram dijual di pasar, akan tetapi selama \pm 1 tahun terakhir bahkan sampai penelitian ini dilakukan kripik jamur tiram selalu habis terjual di rumah.

Penerimaan adalah jumlah penghasilan produksi dalam satuan fisik dikalikan dengan harga jual, yang didefinisikan sebagai nilai uang yang diterima. Tujuan akhir dari pengelolaan usahatani adalah perolehan besarnya pendapatan tunai atau proporsi penerimaan yang dapat digunakan sebagai perbandingan keberhasilan antar pelaku usaha (Saragih, 2001).

Penerimaan yang diterima oleh pelaku usaha budidaya jamur tiram adalah sebesar Rp. 16.038.000,-/PP, dan biaya produksi yang dikeluarkan adalah Rp. 5.084.303,-./PP. Besarnya biaya produksi yang dikeluarkan akan mempengaruhi pendapatan yang diterima oleh pelaku usaha. Besarnya pendapatan yang diperoleh adalah Rp. 10.953.697,-/PP (Rp. 2.738.424,-/Bulan). 
Sedangkan penerimaan yang diterima oleh pelaku usaha pembuatan kripik jamur tiram adalah sebesar Rp. 4.410.000,-/PP, dan biaya produksi yang dikeluarkan adalah Rp. 3.421.563,./PP. Pendapatan yang diperoleh adalah Rp. 988.437,-/PP (Rp. 3.953.748,-/Bulan). Pendapatan yang lebih besar merupakan alasan bagi pelaku usaha untuk menambah cadangan sebuah usaha baru. Oleh karena itu, pelaku usaha perlu membuat perbandingan apakah perlu mengganti usaha yang kurang menguntungkan atau menambah usaha yang lain.

Analisis nilai tambah usaha pengolahan jamur tiram segar menjadi kripik jamur tiram dilakukan untuk mengetahui besarnya nilai yang ditambahkan pada bahan baku yang digunakan dalam memproduksi kripik jamur tiram. Analisis nilai tambah ripik jamur tiram dengan produk akhir yang diterima adalah nilai yang diberikan atau dijual dari pelaku usaha kepada konsumen. Biaya antara yang dikeluarkan pelaku usaha tidak ada, karena tidak ada bahan lain yang digunakan selain bahan baku (jamur tiram segar). Semakin besar nilai tambah maka akan semakin besar keuntungan yang diperoleh dan juga sebaliknya. Nilai tambah pada pengolahan jamur tiram segar rata-rata adalah Rp. 1.305.937,-/PP diperoleh dari selisih nilai akhir dengan biaya bahan baku, dan untuk nilai tambah per $\mathrm{kg}$ diperoleh sebesar Rp. $12.437,-/ \mathrm{Kg}$.

\section{IV.KESIMPULAN DAN SARAN}

\section{A. Kesimpulan}

Berdasarnya hasil penelitian dan analisis yang telah dilakukan, maka dapat ditarik kesimpulan sebagai berikut:

1. Pendapatan yang diperoleh pelaku usaha budidaya jamur tiram adalah sebesar Rp. 10.953.697,-/PP (Rp. 2.738.424,-/Bulan). Sedangkan untuk usaha pembuatan kripik jamur tiram adalah sebesar Rp. 988. 437,-/PP (Rp. 3.953.748,-/Bulan). Adanya perbedaan pendapatan yang cukup besar menyebabkan usaha pembuatan kripik jamur tiram layak untuk dikembangkan.

2. Nilai tambah pada usaha pembuatan kripik jamur tiram adalah Rp. $12.437,-/ \mathrm{Kg}$ atau sebesar Rp. 1.305.937,-/PP (Rp. 5.223.748,/Bulan) yang diperoleh dari dari selisih nilai akhir dengan biaya bahan baku.

\section{B.Saran}

Berdasarkan hasil pembahasan dan kesimpulan yang ada di atas maka saran yang dapat diberikan oleh peneliti adalah:

1. Pelaku usaha budidaya jamur tiram sebaiknya menjaga kualitas kesegaran produk dengan menggunakan alat pendingin (kulkas), serta menggunakan media tanam yang permanen.

2. Pelaku usaha pembuatan kripik jamur tiram sebaiknya memberikan lebel/merk pada setiap kemasan produknya serta menganekaragamkan rasa sehingga konsumen tidak bosan.

\section{DAFTAR PUSTAKA}

Arsyad, L. 2003. Ekonomi Manajerial. Edisi Kelima. Balai Pustaka. Yogyakarta.

Assauri. 2006. Manajemen Produksi dan Operasi. Fakultas Ekonomi UI. Jakarta.

Cahyana, YA. 2008. Jamur Tiram. Penebar Swadaya. Jakarta.

Departemen Pertanian. 2007. Modul Pelatihan Kebijakan Pembangunan Pertanian. Jakarta.

Djarijah, Nanang Marlina dan Abbas Siregar Djarijah. 2010. Budidaya Jamur Tiram Pembibitan Pemeliharaan dan Pengendalian Hama Penyakit. Kanisius. Yogyakarta.

Etta, M. S. dan Sopiah. 2010. Metodelogi Penelitian. ANDI. Yogyakarta.

Faizul. 2009. Ekonomi Makro. Graha Ilmu. Yogyakarta.

Hernanto, F. 2010. Ilmu Usahatani. Penebar Swadaya. Jakarta.

Ibrahim. 2009. Study Kelayakan Bisnis. Rineka. Jakarta.

Joersan. 2003. Teori Ekonomi Mikro. Salemba Empat. Jakarta.

Kam, O. N. 2000. Daftar Analisis Bahan Makanan. Fak. Kedokteran Universitas Indonesia. Jakarta.

Krisnamurthi, B. 2004. Analisis Grand Strategi Pembangunan Pertanian: Pembangunan Sistem dan Usaha Agribisnis dan Implementasi Pembangunan Pertanian. Jakarta.

Kuswadi. 2007. Analisis Keekonomian Proyek. Andi Offset. Yogyakarta.

Manullang. 2003. Analisis Harga. LP3ES. Jakarta.

Mulyadi. 2007. Akuntansi Biaya, Edisi Kelima. Graha Ilmu. Yogyakarta.

Redaksi Trubus. 2004. Pengalaman Pakar dan Praktisi Budidaya Jamur. Penebar Swadaya. Jakarta. 
Saragih, B. 2001. Suara dari Bogor Membangun Sistem Agribisnis. Yayasan USESE bekerjasama dengan SUCOFINDO. Bogor.

Samoelson dan Naredhous. 2000. Pemasaran Produksi Pertanian dan Pengkajian Pemasaran Komoditas. IPB. Bogor.

Sjarkowi, F dan Marwan, S. 2004. Manajemen Agribisnis. Baldad Grafika Press. Palembang.

Sjarkowi, F. 2010. Manajemen Pembangunan Agribisnis. Baldad Grafika Press. Palembang.

Sinaga, MS. 2007. Jamur Tiram dan Budidayanya. Penebar Swadaya. Jakarta.
Sopiah. 2010. Metodelogi Penelitian Pendekatan Praktis dalam Penelitian. C.V. ANDI Offset. Yogyakarta.

Soekartawi. 2001. Prinsip Dasar Komunikasi Pertanian. UI Press. Jakarta.

Sunarjono. 2005. Bertanam 30 Jenis Sayur. Penebar Swadaya. Jakarta.

Sudiyono. 2004. Kelayakan Usaha. Balai Pustaka. Yogyakarta.

Sriawiria, U. 2010. Budidaya Jamur Tiram. Kanisius. Yogyakarta.

Tarigan, R. 2005. Ekonomi Regional Teori dan Aplikasinya. Bumi Aksara. Medan. 